\title{
АДМІНІСТРАТИВО-ПРАВОВЕ РЕГУЛЮВАННЯ ОРГАНІЗАЦІї ДІЯЛЬНОСТІ КАПІТАНА У СФЕРІ ВОДНОГО ТРАНСПОРТУ: ЗАКОННІСТЬ, ПОВНОВАЖЕННЯ ТА ФУНКЦІї
}

Байрак В. В.

У статmі розглянуто теоретичні питання та практична необхідність забезпечення законності у сфері діяльності капітана водного транспорту. Охарактеризовано окремі аспекти забезпечення законності з точки зору як загальної теорії права, адміністративного права, так $і$ міжнародних норм, що залишаються одними з пріоритетних напрямків інтеграції України до світового співтовариства. Виділено проблемні аспекти, що виникають у процесі правозастосування у сфері водного транспорту. Проведено порівняльний аналіз стану нормативно-правового регулювання адміністративних функцій капітана судна щодо здійснення затримання особи з визначеним порядком здійснення кримінально-процесуального затримання особи. Наведено приклади сучасного стану розвитку законодавства внутрішнього водного транспорту України і Молдови. Запропоновано теоретичні і практичні напрямки щодо вдосконалення законодавства у сфері організації управління на водному транспорті.

Ключові слова: водний транспорт, капітан судна, правове регулювання, законність, повноваження капітана судна, функції капітана судна, адміністративне затримання, розгляд справ про адміністративні правопорушення, накладення адміністративних стягнень.

В статье рассмотрены теоретические вопросы и практическая необходимость обеспечения законности в сфере деятельности капитана водного транспорта. Охарактеризованы отдельные аспекты обеспечения законности с точки зрения как общей теории права, административного права, так и международных норм, остающихся одними из приоритетных направлений интеграции Украины в мировое сообщество. Выделены проблемные аспекты, возникающие в процессе правоприменения в сфере водного транспорта. Проведен сравнительный анализ нормативно-правового регулирования административных функций капитана судна по осуществлению задержания лица с определенным порядком осуществления уголовно-процессуального задержания лица. Приведены примеры современного состояния развития законодательства внутреннего водного транспорта Украины и Молдовы. Предложены теоретические и практические направления по совершенствованию законодательства в сфере организации управления на водном транспорте.

Ключевые слова: водный транспорт, капитан судна, правовое регулирование, законность, полномочия капитана судна, функции капитана судна, административное задержание, рассмотрение дел об административных правонарушениях, наложение административных взысканий.

The article deals with theoretical issues and the practical necessity of ensuring legality in the activities of a water vessel captain. There is description of some aspects of ensuring legality through the prism of the general theory of law, administrative law and international norms, which remain one of the priority directions of Ukraine's integration into the world community. The legal regulation of the captain's activity on water transportation has been analyzed. The managerial functions of the captain of a vessel has been described.
The problematic aspects that arise in the process of law enforcement in the field of water transportation have been highlighted. The legal regulation of the administrative functions of a vessel captain in the field of person's detention have been compared to some procedures of a criminal-procedural detention. The margins of administrative and procedural powers of a watertransportation captain have been determined.

There are examples of current development of the legislation regulating inland water transportation of Ukraine and Moldova. The theoretical and practical ways of the legislation improvement in the field of management organization on water transportation have been offered.

The legal nature of ensuring legality by the captain on a ship has revealed. The author's definition of administrative-organizational functions of a vessel captain has been given.

The evaluation of the legal mechanism for the implementation of the administrative powers and functions of the captain on water transportation enshrined in subordinate normative acts has been made.

The basis for further theoretical investigations and normative process for providing sustainable development and organization of effective management in the field of water transportation in Ukraine has been outlined.

Key words: water transportation, ship captain, legal regulation, legality, authority, vessel captain powers, vessel captain functions, administrative detention, proceeding of administrative violations, imposition of administrative penalties.

Постановка проблеми. Реформування публічного управління щодо питання розвитку законодавства України в останні десятиліття розглядалося як найважливіше завдання суспільства та держави, хоча окремі рішення органів публічної влади в деяких випадках не можна вважати достатньо послідовними. Разом із тим правовий нігілізм, що характерний для початкового етапу реформування українського законодавства, починає поступатися місцем впорядкованому суспільному нагляду та контролю в різних сферах суспільних відносин в тому числі й щодо правового регулювання діяльності транспорту.

Важливу роль водного транспорту в сучасному механізмі української економіки важко переоцінити. Морський та річковий транспорт $\epsilon$ одним із основних видів транспорту та єдиним, що здійснює перевезення вантажів і пасажирів водними шляхами. За його роботою можна робити висновок про життєздатність усього народногосподарського комплексу країни. У зв'язку із цим дуже важливо, щоб законодавство про водний транспорт повністю та чітко регулювало усі сфери діяльності в даній галузі, а ступінь дотримання законності в організації управління на торговому судні відповідав належному рівню.

Аналіз останніх досліджень. Адміністративно-правовим питанням організації діяльності транспорту при- 
свячено праці українських науковців, таких, зокрема, як: В. Авер'янов, Т. Аверочкіна, О. Бандурка, В. Бевзенко, Ю. Битяк, Г. Бондаренко, І. Голосніченко, С. Гончарук, Є.Додін, Д. Калаянов, С. Ківалов, Л.Коваль, В. Колпаков, А. Комзюк, С. Кузніченко, С. Кузнецов, О. Кузьменко, О. Літошенко, Д. Лукянець, О. Миколинко, Н. Нижник, В. Олефір, В. Опришко, І. Підпала, В. Шкарупа, Ф. Шульженко, Х. Ярмакі, О. Ярмиш та інші. Проте, незважаючи на вагомий науковий вклад учених, убачається відсутність ґрунтовних досліджень із питань, що характеризують окремі адміністративно-організаційні питання управління в галузі водного транспорту України.

Виклад основного матеріалу. У Морській доктрині України на період до 2035 року говориться, що Україна має сприятливі умови для розвитку морської діяльності, проте негативний вплив процесів, характерних для всієї економіки країни, спричиняє загострення комплексу економічних, соціальних та інших проблем, зумовлює різке зниження обсягів виробництва у сфері морської діяльності.

Виходячи із просторових та геофізичних особливостей, місця і ролі у глобальній та регіональній системі міжнародних відносин, Україна повинна дотримуватися міжнародних стандартів безпеки мореплавства та охорони суден і портів. Імплементація міжнародно-правових норм вимагає наявності чітко структурованої системи забезпечення безпеки мореплавства і охорони суден та портових засобів, що має належні організаційні, кадрові та матеріальні ресурси і сучасну правову базу. Для підвищення ефективності зазначеної структури необхідно вдосконалити наявну нормативно-правову базу, усунувши колізії в законодавстві, вжити дієвих заходів для зміцнення зв'язків між суб'єктами системи управління морською діяльністю держави [1].

Розглядаючи стан нормативно-правового регулювання діяльності у сфері управління водним транспортом, варто зазначити, що юридичною основою, яка породжує правовідносини на основі законності, $\epsilon$ нормативно-правовий акт як джерело права. I не просто акт - окремий документ, яким урегульований певний вид правовідносин, а їхня сукупність - цілісний і погоджений комплекс нормативно-правових приписів, що містяться в законах та підзаконних актах і згруповані залежно від предмета і метода правового регулювання діяльності, що в теорії права, як відмічає О.Ф. Скакун, розуміється як система нормативно-правових актів або система законодавства [2, с. 237].

Міжнародні договори України, на наш погляд, також відносяться до загального поняття «система законодавства», ураховуючи рішення Конституційного суду України у справі за конституційним зверненням Київської міської ради професійних спілок щодо офіційного тлумачення частини третьої статті 21 Кодексу законів про працю України, з приводу тлумачення терміну «законодавство», у відповідності до якого «поняття «законодавство», яке уживається в законах України, треба розуміти так, що ним охоплюються закони України, чинні міжнародні договори України, згода на обов'язковість яких надана Верховною Радою України, а також постанови Верховної Ради України, укази Президента України, декрети і постанови Кабінету Міністрів України, прийняті в межах їх повноважень та відповідно до Конституції України і законів України» [3].
Таке трактування, у свою чергу, на наш погляд, виводить поза систему законодавства підвідомчі галузеві нормативно-правові акти - офіційні документи, прийняті уповноваженим на це суб'єктом нормотворчості у визначеній законом формі та порядку, який встановлює норми права для неозначеного кола осіб і розрахований на неодноразове застосування [4].

Аналіз окремих норм адміністративного права України свідчить, що національне законодавство не завжди вчасно корегується у відповідності до вимог міжнародних норм. Зокрема, згідно з Конвенцією про полегшення міжнародного морського судноплавства 1965 року [5], яка набула чинності в Україні 24 грудня 1993 року, пунктом 3.19.3. визначено, що члени команди не зобов'язані з метою звільнення на берег мати спеціальний дозвіл, як, наприклад, перепустку для звільнення на берег. На відміну від цього, у відповідності до статті 207 Кодексу України про адміністративні правопорушення [6] було передбачено адміністративну відповідальність за неповернення капітаном іноземного судна, крім військового, на контрольно-пропускний пункт перепусток на право сходження на берег осіб суднового екіпажу і перебування їх на території порту і портового міста під час стоянки судна в порту України, за винятком випадків неподання перепустки внаслідок самовільної неявки особи суднового екіпажу. Дана норма втратила чинність лише 27 лютого 2018 року [7].

Як ми можемо спостерігати, така колізія між нормами міжнародного та адміністративного права існувала продовж майже 25 років, чим створювала протиріччя та труднощі у правозастосуванні у сфері організації діяльності капітана іноземного судна. У даному випадку має місце факт відсутності гармонізації норм адміністративного права, що безпосередньо впливає на можливість вирішення управлінських завдань, які зумовлюють належну реалізацію повноважень капітана торгового судна в умовах очевидних суперечностей у механізмі нормативно-правового регулювання.

Щодо з'ясування окремих адміністративних повноважень капітана судна, то, на наш погляд, необхідно провести порівняльний аналіз з наданими йому кримінально-процесуальними повноваженнями.

У відповідності до ст. 519 Кримінального процесуального кодексу України (КПКУ) капітан судна України несе відповідальність в разі вчинення кримінального правопорушення на повітряному, морському чи річковому судні, що перебуває за межами України під прапором або з розпізнавальним знаком України, якщо це судно приписано до порту, розташованого в Україні [8].

Крім того, у ст. 67 Кодексу торговельного мореплавства України (КТМУ) зазначено, що капітан судна, як службова особа, уповноважений на вчинення процесуальних дій у кримінальному провадженні. Якщо на судні, що перебуває у плаванні, вчиняються діяння, передбачені законом України про кримінальну відповідальність, капітан судна уповноважений на вчинення процесуальних дій у порядку, передбаченому кримінальним процесуальним законодавством України та відповідною Інструкцією, яка затверджується Генеральним прокурором за погодженням із центральним органом виконавчої влади, що забезпечує формування та реалізує державну політику у сферах морського і річкового транспорту, та центральним органом виконавчої влади, що забезпечує формування державної політики у сфері рибного господарства. 
Капітан судна має право затримати особу, яка підозрюється у вчиненні кримінально караного діяння, до передачі їі відповідним правоохоронним органам у першому порту України. У разі необхідності капітан судна може направити цю особу і зібрані матеріали в Україну на іншому судні, зареєстрованому в Україні.

У разі вчинення діяння, передбаченого законом України про кримінальну відповідальність, під час перебування судна в порту України капітан судна зобов'язаний передати особу, яка підозрюється у вчиненні цього діяння, відповідним правоохоронним органам у порядку, встановленому кримінальним процесуальним законодавством України [9].

Як зазначено в п. 4.2.2. «Ннструкції про порядок проведення процесуальних дій під час кримінального провадження на морському чи річковому судні України, що перебуває за межами України під прапором або з розпізнавальним знаком України», якщо це судно приписано до порту, розташованого в Україні, капітан судна (уповноважена особа) має право без ухвали слідчого судді, суду затримати особу, підозрювану у вчиненні злочину, за який передбачене покарання у вигляді позбавлення волі, лише у випадках:

1) якщо цю особу застали під час вчинення злочину або замаху на його вчинення;

2) якщо безпосередньо після вчинення злочину очевидець, у тому числі потерпілий, або сукупність очевидних ознак на тілі, одязі чи місці події вказують на те, що саме ця особа щойно вчинила злочин.

Пункт 4.2.7. Інструкції визначає, що капітан судна (уповноважена особа) має право затримати особу на строк, необхідний для ії доставляння на територію України, та здійснити при цьому обшук затриманої особи з дотриманням правил, передбачених частиною сьомою статті 223 і статтею 236 КПК України [10].

Зрозуміло, в даному випадку мова йде про право капітана судна як посадової особи, уповноваженої на вчинення процесуальних дій у кримінальному провадженні, тобто застосовувати заходи кримінального процесуального примусу, що відноситься в системі права до галузі кримінально процесуального права. Для порівняння, норма статті 65 Кодексу торгового мореплавства України дозволяє виділити повноваження капітана судна щодо застосування, як на наш погляд, адміністративного примусу, а саме адміністративного затримання.

Так, зокрема, у статті 65 Кодексу торгового мореплавства України щодо питань підтримання порядку на судні відмічається: «якщо дії особи, яка перебуває на судні, не містять кримінально караного діяння, але загрожують безпеці судна або людей і майна, що на ньому перебувають, капітан судна має право ізолювати цю особу в окремому приміщенні» [9].

Аналіз чинного законодавства України, зокрема змісту статей 261-262 Кодексу України про адміністративне правопорушення (КУПАП), свідчить, що адміністративне затримання особи може здійснюватись лише за вчинення адміністративного правопорушення, а також може провадитися лише органами (посадовими особами), уповноваженими на те законами України [6]. Серед зазначених у статті 262 КУПАП органів (посадових осіб), що мають право здійснювати адміністративне затримання, капітан судна не зазначається.

У даному випадку ми спостерігаємо наглядний приклад відсутності чіткого механізму правового регулю- вання окремих повноважень капітана судна. Вважаємо за необхідне порушити питання про розширення тлумачення норми права, що визначена статтею 65 КТМУ, 3 наступним закріпленням зазначених особливостей правозастосування у чинному законодавстві, як це наразі зазначено в КПКУ, КТМУ та в Інструкції Генеральної прокуратури України, де послідовно деталізовано повноваження та функції капітана судна відомчим підзаконним нормативним актом щодо здійснення затримання.

Як стверджує $Є$. Гетьман, підзаконні нормативно-правові акти виконують перш за все регулятивну функцію, яка, у свою чергу, поділяється на функцію первинного (під час первинного встановлення норм права підзаконними нормативно-правовими актами) та вторинного (у процесі конкретизації, розвитку та вдосконалення норм права, установлених нормативно-правовими актами вищої юридичної сили) регулювання; управлінську функцію; роз'яснювальну та конкретизуючу функції (норми, які містяться в підзаконних нормативно-правових актах, конкретизують, роз'яснюють, удосконалюють норми, встановлені нормативно-правовими актами вищої юридичної сили); правоустановчу функцію (реалізується під час введення норм права підзаконними нормативно-правовими актами); правореалізаційну функцію (норми підзаконних нормативно-правових актів закріплюють певні порядки, положення, реалізація яких практично відтворює норми, установлені Конституцією, кодексами та законами України) [11].

Зазначені автором функції реалізовуються і в порядку організації діяльності капітана водного транспорту як суб'єкта управління у формі видання владних розпоряджень, чим зумовлюють його адміністративно-правовий статус як посадової особи юридичних осіб публічного права.

Ми вважаємо, адміністративно-організаційні функції капітана - це здійснення керівництва, що реалізується сукупністю методів, прийомів та способів щодо забезпечення управління на судні або в порту, які складають механізм публічно-владного впливу капітана як суб'єкта управління на об'єкт управління й об'єктивно проявляються у формуванні організаційних відносин у сфері діяльності водного транспорту, що ґрунтуються на рішеннях капітана на підставі норм права (на законах, указах, постановах, наказах, розпорядженнях, вказівках, інструкціях), які регламентують морську діяльність у межах повноважень капітана, забезпечуючи ефективну організацію у відповідності до належного вирішення визначених завдань.

Окремо слід наголосити, що в Україні дотепер не прийнято базового Закону «Про внутрішній водний транспорт». Він так і залишається у стані проекту, який зареєстровано у Верховній Раді України ще 4 серпня 2015 р. [12]. Правовідносини у сфері функціонування внутрішнього водного транспорту i зараз регулюються Статутом внутрішнього водного транспорту Радянського Союзу, підзаконним актом затвердженого Радою Міністрів СРСР 15.10.1955 р. [13], положення якого, звісно, не відповідають сучасним відносинам, а в більшості своїй суперечать чинному національному та міжнародному законодавству, що суттєво ускладнює вирішення окремих питань організації діяльності капітана судна на внутрішніх водних шляхах України.

Як приклад можна навести стан законодавчого регулювання на внутрішніх водних шляхах Республіки Мол- 
дова. Незважаючи на низький потенціал внутрішнього водного транспорту в порівнянні з Україною (в Республіці Молдова протікають два внутрішніх водних шляхи вільного перебігу - річки Дністер і Прут) [15], парламентом Республіки Молдова 2 липня 2013 р. було прийнято Закон «Про внутрішній водний транспорт Республіки Молдова». Даний Закон встановлює спеціальні положення, що застосовуються до внутрішнього водного транспорту Молдови, порядок організації інституційної системи в даній області, спеціальні положення про здійснення безпечного судноплавства на внутрішніх водних шляхах, а також фундаментальні вимоги, застосовні до судів, екіпажу і осіб, які здійснюють діяльність в області водного транспорту [14].

Висновки. Забезпечення законності покладає певні обов'язки як на публічну владу, так і на громадян. Для перших це полягає в забезпеченні прав і свобод громадян шляхом прийняття і виконання нормативних актів, що мають відповідну юридичну силу, а також у стабільній та ефективній роботі органів публічної влади щодо впорядкування законодавства, з мінімізацією суперечностей і колізій, що забезпечується правилами юридичної техніки; для других - у дотриманні загальнообов'язкових норм права, які гармонійно поєднуються 3 міжнародними нормами.

У зв'язку з вищевикладеним пропонується створення належного механізму адаптації адміністративно-правових конструкцій національного законодавства у відповідності до міжнародних норм права. На наш погляд, варто звернутись до прикладу функціонування універсальних організаційно-правових систем різних країн світу, де мають місце подібні адміністративні практики, узагальнивши і синтезувавши їх, що завчасно дозволить створювати оновлені національні нормативно-правові механізми, в основу яких покладено міжнародні правовідносини.

Висновки. На основі аналізу чинних законів та підзаконних актів, які регулюють адміністративну діяльність капітана в системі водного транспорту, можна зробити висновок, що доктринальні основи вироблення державної політики в зазначеній галузі та безпосередня реалізація капітаном належних йому адміністративно-організаційних функцій повинні мати цілісну і деталізовану правову форму, яка зумовить ефективне забезпечення реалізації правозастосування в різних сферах діяльності на водному транспорті. Правовий механізм реалізації адміністративних повноважень та функцій капітана щодо організації діяльності на водному транспорті із часу формування українського законодавства в даній сфері до теперішнього часу, на нашу думку, недостатньо послідовно викладено в підзаконних нормативних актах, що створює наразі суперечності та труднощі у правозастосуванні.

Сучасний стан законодавства України та держав пострадянського простору, а також запропоновані нами шляхи вирішення проблемних питань нормативно-правового регулювання на прикладі цих держав, на наш погляд, можуть стати основою для подальших теоретичних розвідок і нормотворчого процесу щодо забез- печення сталого розвитку та організації ефективного управління у сфері водного транспорту України.

\section{Література}

1. Про затвердження Морської доктрини України на період до 2035 року : Постанова Кабінету Міністрів України від 7.10.2009 № 1307. URL: https://zakon.rada.gov.ua/ laws/show/1307-2009-п.

2. Скакун О.Ф. Теорія держави і права : підручник. Харків : Консум, 2001. 656 c. URL: http://ukrkniga.org.ua/ ukrkniga-text/34/32/.

3. Рішення Конституційного Суду України у справі за конституційним зверненням Київської міської ради професійних спілок щодо офіційного тлумачення частини третьої статті 21 Кодексу законів про працю України (справа про тлумачення терміну «законодавство») від 9 липня 1998 № 12-pп/98. URL: http://zakon2.rada.gov.ua/laws/show/ v012p710-98.

4. Про внесення змін до Порядку подання нормативно-правових актів на державну реєстрацію до Міністерства юстиції України та проведення їх державної реєстрації : Наказ Міністерства юстиції від 15.05.2013 № 883/5. URL: http://zakon4.rada.gov.ua/laws/show/z0742-13/ paran15\#n15.

5. Конвенція про полегшення міжнародного морського судноплавства 1965 року. URL: http://zakon.rada.gov.ua/ laws/show/995 064.

6. Кодекс України про адміністративні правопорушення від 07.12.1984 № 8073-Х. Відомості Верховної Ради УРСР. 1984. Додаток до № 51. Ст. 1122.

7. Про внесення змін до деяких законодавчих актів України щодо забезпечення прикордонної безпеки держави : Закон України від 27.02.2018 № 2293-VIII. Відомості Верховної Ради України. 2018. № 19. Ст. 180.

8. Кримінальний процесуальний кодекс України. URL: https://zakon.rada.gov.ua/laws/show/4651-17.

9. Кодекс торговельного мореплавства України. URL: https://zakon.rada.gov.ua/laws/show/4651-17. https:// zakon.rada.gov.ua/laws/show/176/95-вр.

10. Інструкція про порядок проведення процесуальних дій під час кримінального провадження на морському чи річковому судні України, що перебуває за межами України під прапором або з розпізнавальним знаком України, якщо це судно приписано до порту, розташованого в Україні : Наказ Генерального прокурора України від 14.11.2012 № 112. URL: http://www.gp.gov.ua.

11. Гетьман Є.А. Підзаконний нормативно-правовий акт:поняття, ознаки, функції, види. Вісник Національної академії правових наук України. 2014. № 2. С. 9.

12. Проект Закону «Про внутрішній водний транспорт». URL: http://w1.c1.rada.gov.ua/pls/zweb2/webproc4_1?pf35 $11=56230$.

13. Устав внутреннего водного транспорта Союза ССР : Постановление Совета Министров СССР от 15.10.1955 № 1801. URL: https://zakon.rada.gov.ua/laws/show/ v1801400-55.

14. О внутреннем водном транспорте Республики : Закон Республики Молдова № 176 от 12 июля 2013 г. (Официальный Монитор РМ № 238 -242 от 25 октября 2013 г.).

15. Концепция развития водного транспорта в Республике Молдова. URL: https://refdb.ru/look/2183065.html.

Байрак В. В., аспірант

Інституту законодавства Верховної Ради України 